\title{
Diversity and seasonality of Pseudo-nitzschia (Peragallo) at two North Sea time-series monitoring sites
}

\author{
Eileen Bresnan • Alexandra Kraberg • \\ Sheila Fraser • Lyndsay Brown - Sarah Hughes • \\ Karen H. Wiltshire
}

Received: 19 May 2014/Revised: 12 February 2015/Accepted: 19 February 2015/Published online: 13 March 2015

(C) Crown Copyright as represented by: Ms Helen McGregor, Marine Scotland Science 2015

\begin{abstract}
Species within the diatom genus Pseudo-nitzschia (Peragallo) have been identified as producers of domoic acid, the toxin responsible for amnesic shellfish poisoning. Toxin- and non-toxin-producing species of Pseudo-nitzschia have been reported globally; however, as Pseudo-nitzschia species cannot be routinely identified to species level using light microscopy, cells are rarely recorded to species level during long-term monitoring studies. Here, we report the results of a comparative survey of Pseudo-nitzschia species at two monitoring sites in the North Sea: Stonehaven on the east coast of Scotland and Helgoland Roads in the German Bight. A difference in the seasonality of this genus was observed between the sites with Pseudo-nitzschia cells playing a major role in the spring bloom as well at the summer and autumn diatom community at Stonehaven. In contrast, Pseudo-nitzschia was abundant only during the summer months at Helgoland. Pseudo-nitzschia cells constitute a higher proportion of the diatom community at Stonehaven than at Helgoland, particularly during the late summer, autumn and winter and thus may be considered more 'ecologically important' at this site. A total of eight different species were recorded during this survey with five Pseudo-nitzschia species observed at the Helgoland site: P. pungens, $P$.
\end{abstract}

Communicated by H.-D. Franke.

E. Bresnan $(\bowtie) \cdot S$. Fraser $\cdot$ L. Brown $\cdot$ S. Hughes

Marine Laboratory, Marine Scotland Science, 375 Victoria

Road, Aberdeen AB11 9DB, UK

e-mail: E.Bresnan@marlab.ac.uk

A. Kraberg - K. H. Wiltshire

Biologische Anstalt Helgoland, Alfred Wegener Institute for

Polar and Marine Research, Kurpromenade 201,

27498 Helgoland, Germany fraudulenta, $P$. americana, $P$. cf. delicatissima and the potentially toxic species $P$. multiseries. Six species were also recorded at Stonehaven; $P$. australis, $P$ cf. delicatissima, $P$. pungens, $P$. cf. pseudodelicatissima, $P$. subpacifica and $P$. seriata. This study represents the first examination of the seasonality of Pseudo-nitzschia species around Helgoland and the first comparison between two long-term monitoring sites in the North Sea. P. americana and $P$. multiseries are also recorded at the Helgoland Roads time-series site for the first time.

Keywords Pseudo-nitzschia · Diversity · North Sea · Time series · Helgoland · Stonehaven

\section{Introduction}

The diatom genus Pseudo-nitzschia (Peragallo) is the focus of considerable international scientific attention due to the production by some species of the amnesic shellfish toxin domoic acid (DA) (Hasle 2002; Trainer et al., 2012). Since the discovery of DA associated with human mortalities in the late 1980s, the presence of toxin-producing Pseudonitzschia species has been confirmed worldwide (Villac et al. 1993; Hasle 2002; Lelong et al. 2012; Trainer et al. 2012). DA contamination in shellfish has been reported from many European states particularly along the Atlantic (Hasle 2002) and Mediterranean coasts (Costa and Garrido 2004). In the North Sea, the occurrence of ASP has been reported from northern regions; Scotland, Norway, Denmark and Sweden (Gallacher et al. 2001; Hasle 2002; Fehling et al. 2006; Trainer et al. 2012). Reports of DA and shellfish closures from the southern North Sea are less frequently recorded although Pseudo-nitzschia cells are observed in the water column with reports from the 
Netherlands, English Channel and the north coast of France (Vrieling et al. 1996; Percy et al. 2006; Downes-Tettmar et al. 2013).

Long-term phytoplankton time series are considered essential for the examination of changes in the marine ecosystem with many of the current European environmental assessments being made on an ocean-scale system (McQuatters-Gollop 2012). Within the North Sea region, data from two long-term phytoplankton time series, Helgoland Roads, Germany (south east North Sea), and Stonehaven, Scotland (north-west North Sea), are currently being used to identify variations and changes to the phytoplankton community over time (Wiltshire et al. 2008; Bresnan et al. 2009; Löder et al. 2012)).

In Scotland, Pseudo-nitzschia is observed in phytoplankton samples throughout the year (Fehling et al. 2006; Turrell et al. 2008). This genus is considered a key member of the phytoplankton community in this region, and $P$. australis and $P$. seriata are confirmed as DA producers (Fehling et al. 2004). Although it is not possible to routinely identify Pseudo-nitzschia cells using light microscopy, they can be separated into different size categories. An examination of Pseudo-nitzschia in Scotland has identified a distinct seasonality within this genus. Pseudo-nitzschia 'delicatissima-type' cells (diameter $<3 \mu \mathrm{m}$ ) dominate in the spring time of the year, while Pseudo-nitzschia 'seriata-type' cells (diameter $>3 \mu \mathrm{m}$ ) dominate in the late summer/early autumn (Fehling et al. 2004; Brown and Bresnan 2008). The diversity of Pseudo-nitzschia is considered high in Scottish waters with transmission electron microscopy (TEM) used for identifying 13 species to date (Fehling et al. 2004; Bresnan et al. 2008; Brown and Bresnan 2008; Turrell et al. 2008). For comparison, nine species have been identified in sediments of the Mariager Fjord in Denmark (Lundholm et al. 2010). As well as being the identified cause of extensive closures of the offshore scallop fishing grounds at the end of the 1990s (Gallacher et al., 2001), DA has also been reported in the faeces, urine and amniotic fluid in seals (Phoca vitulina) from Scottish waters (Hall and Frame 2010). Pseudo-nitzschia has been less problematic in the southern North Sea; however, P. multiseries was identified as a DA producer in the Wadden Sea and English Channel (Vrieling et al 1996; Percy et al. 2006). Investigations into the dynamics of Pseudo-nitzschia in the English Channel has shown that DA detected in the water column was associated with the ' $P$. seriata' group ( $>3 \mu \mathrm{m}$ diameter) as identified by light microscopy (DownesTettmar et al. 2013). TEM of Pseudo-nitzschia in the eastern English Channel associated DA in the water column with the presence of $P$. australis (Klein et al. 2010).

At the Helgoland long-term monitoring site, Pseudonitzschia is not routinely identified to species level.
Although the most current phytoplankton checklists for Helgoland (Drebes and Elbrächter 1976; Hoppenrath 2004) list Pseudo-nitzschia pungens, $P$. fraudulenta and $P$. delicatissima as occurring around Helgoland, no data about the seasonality of these species are available. A recent cruise in the waters of the German Bight did not detect of DA in the area around Helgoland, and no information was reported about the Pseudo-nitzschia species present (Krock et al. 2013). There has yet to be a detailed study of the diversity of Pseudo-nitzschia species in this area.

Current European directives such as the Water Framework Directive (WFD) and Marine Strategy Framework Directive (MSFD) require the marine waters of member states to achieve 'Good Ecological Status' and 'Good Environmental Status', respectively. Inherent in this is the requirement for an understanding of the dynamics of the phytoplankton community on a regional sea scale. This assessment is not straightforward owing to the paucity of baseline information available. Initiatives to address this are being led by the Oslo-Paris Commission (OSPAR) Intersessional Correspondence Group for Coordinated Biodiversity Assessment and Monitoring (ICG-COBAM). In this study, the diversity and seasonality of Pseudonitzschia is assessed at two long-term monitoring sites (Stonehaven and Helgoland) with a view to identifying regional differences in a key diatom genus.

\section{Methods}

Long-term monitoring sites

The location of the two monitoring stations can be seen in Fig. 1. The Helgoland Roads monitoring site $\left(54^{\circ} 11.3^{\prime} \mathrm{N}\right.$, $7^{\circ} 54.0^{\prime} \mathrm{E}$ ) is located approximately $70 \mathrm{~km}$ from the German mainland in a channel between the main island of Helgoland and a small sandy island (the dune). The water depth varies from 6-8 $\mathrm{m}$ in depth depending on the tide. Further information about this site can be found in Franke et al. (2004) and Wiltshire et al. (2010). Sampling for phytoplankton began at this site in 1962 . The Stonehaven monitoring site $\left(56^{\circ} 57.8^{\prime} \mathrm{N}, 02^{\circ} 06.2^{\prime} \mathrm{W}\right)$ is located $5-\mathrm{km}$ offshore and 50-m depth. Further details can be found in Bresnan et al. (2009). Sampling for phytoplankton began at this site in 1997.

Sampling and analysis methodology

\section{Helgoland}

Surface water samples were collected daily from the Helgoland Roads monitoring site using a bucket. The samples were mixed well, and $100 \mathrm{ml}$ subsample was preserved in 


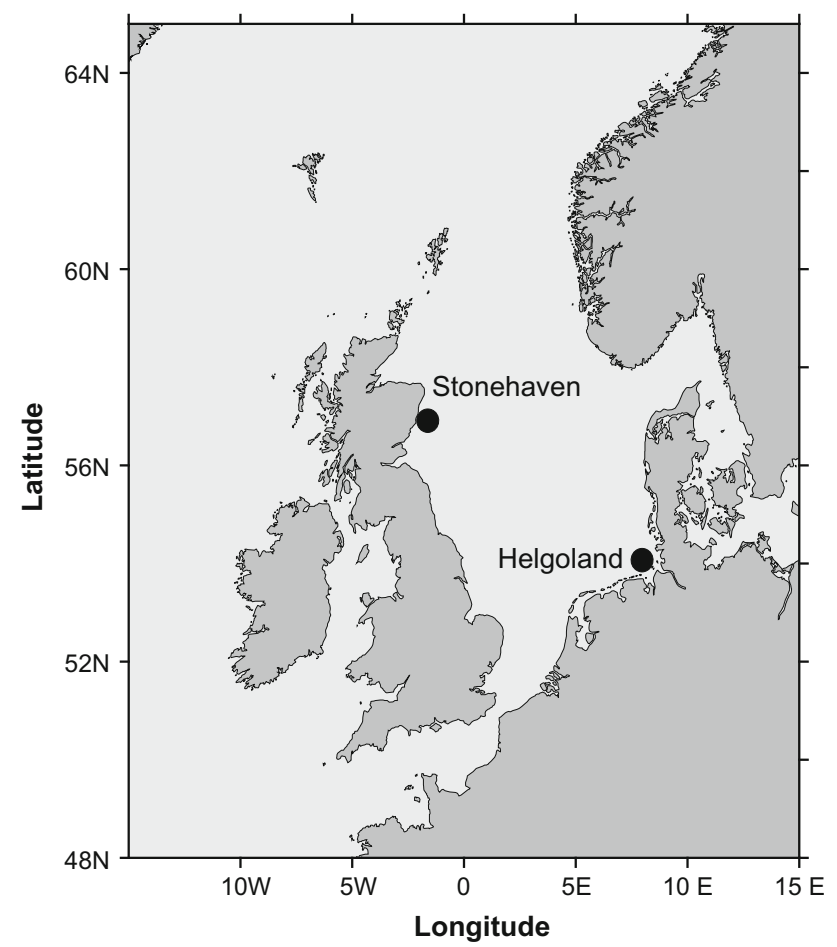

Fig. 1 Map showing location of the Stonehaven and Helgoland Roads time-series monitoring sites

$0.1 \%$ neutral Lugol's iodine and stored in an amber glass bottle before $25 \mathrm{ml}$ is analysed using the Utermöhl method (Lund et al. 1958). These counts provided the baseline data used in this study (see Fig. 2b). In addition, to the bucket samples, net samples were taken twice weekly. Two horizontal hauls with a 20 - and $80-\mu \mathrm{m}$ net were carried out. Samples were fixed in hexamine-buffered formalin (4\%), (Throndsen 1978) and stored in 30-ml amber glass bottles for TEM analysis. Temperature and salinity at this site were measured in the bucket sample using a thermometer and a Guildline salinometer (Autosal, Gamma Analysen Technik $\mathrm{GmbH}$ ), respectively. Temperature and salinity data from 2002 to 2011 are used to describe the seasonal cycle at this site.

\section{Stonehaven}

Samples from the Stonehaven site were collected weekly using a 10-m integrated tube sampler. The sample was well mixed, and $1 \mathrm{~L}$ subsample was preserved in $0.5 \%$ Lugol's iodine (Throndsen 1978). Fifty millilitres of sample was analysed immediately for the presence of Pseudo-nitzschia cells using the Utermöhl method (Lund et al. 1958) and the remaining $950 \mathrm{ml}$ stored in an amber glass jar, in the dark and at $5{ }^{\circ} \mathrm{C}$ before analysis by transmission electron microscopy (TEM). Full community phytoplankton analysis was performed using the Utermöhl technique as described in Bresnan et al. (2009). Niskin bottles fitted with digital reversing thermometers were deployed to surface and 45-m depths to collect water for salinity and chemical nutrient analysis. In some instances, material from zooplankton samples collected by a vertical 40 -cm-diameter bongo (68- $\mu \mathrm{m}$ mesh) net haul from $45 \mathrm{~m}$ to surface was used for TEM analysis. These samples were preserved in $4 \%$ borax-buffered formaldehyde until analysis. Water samples for salinity analysis were stored in 200-ml salinity sample bottles in a temperature-controlled room $\left(21^{\circ} \mathrm{C}\right)$ for at least $24 \mathrm{~h}$ prior to analysis using a Guildline $8410 \mathrm{~A}$ Portasal salinometer. Temperature and salinity surface water data from 2002 to 2011 are used to describe the seasonal cycle at this site.

Pseudo-nitzschia cell counts from 2002 to 2011 were used to examine the temporal abundance of Pseudonitzschia at the two monitoring sites. All cell count data are subject to quality control examination. Identification and enumeration of Pseudo-nitzschia cells using light microscopy received ISO 17025 accreditation at Marine Scotland Marine Laboratory in 2005. Identification of Pseudo-nitzschia cells using TEM was accredited in 2008.

\section{Transmission electron microscopy}

Integrated tube samples from the Stonehaven site were left to stand for 1 week to allow the phytoplankton cells to sink to the bottom of the amber glass jars. The top $900 \mathrm{ml}$ was gently siphoned off and the remaining $50 \mathrm{ml}$ centrifuged at $3000 \mathrm{rpm}$ for $15 \mathrm{~min}$. The supernatant was gently removed leaving a final volume of $5 \mathrm{ml}$. Thirty millilitres of net sample from the Helgoland Roads site was concentrated by centrifuging at $3000 \mathrm{rpm}$ for $15 \mathrm{~min}$. The supernatant was removed leaving a final sample volume of $5 \mathrm{ml}$. Samples were cleaned using the method described by Lundholm et al. 2002, mounted onto 200-mesh Formvar-covered grids and left to air dry before being analysed using a Philips CM10 TEM.

Zooplankton net samples collected during August 2002, July 2003, August 2004 and September 2004 were used to examine material from the Stonehaven monitoring site. In this instance, $5 \mathrm{ml}$ aliquot of material was suspended in $30 \mathrm{ml}$ of distiled water in a $50-\mathrm{ml}$ graduated cylinder. The mixture was inverted up to 20 times to ensure homogenisation. The samples were let settle for $10 \mathrm{~min}$ to let the heavy material (e.g. zooplankton) sink to the bottom. The top $25 \mathrm{ml}$ was siphoned off and concentrated to a volume of $5 \mathrm{ml}$ by centrifuging at $3000 \mathrm{rpm}$ for $15 \mathrm{~min}$. Samples 
Fig. 2 Box plots of monthly temperature and salinity averages from 2002 to 2011 at both monitoring sites: a temperature-Stonehaven, b temperature-Helgoland, c salinity-Stonehaven and d salinity-Helgoland
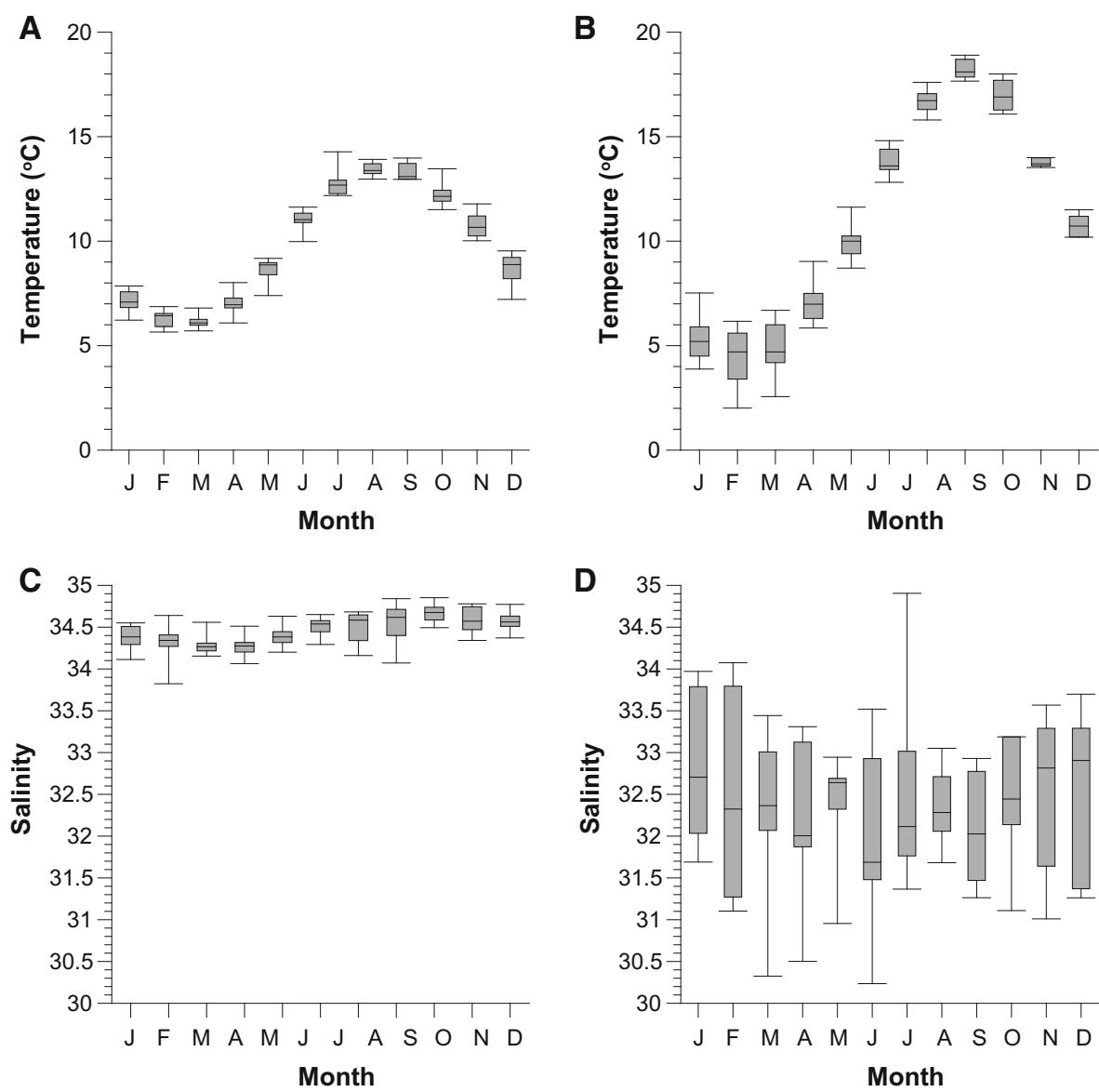

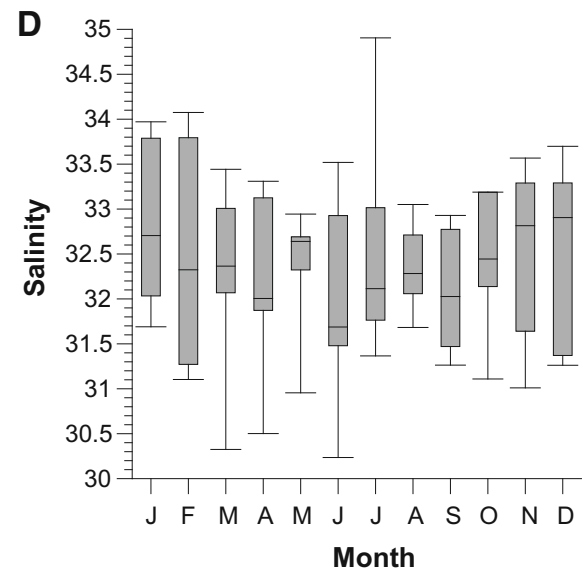

were cleaned using the method described by Lundholm et al. 2002, mounted onto 200-mesh Formvar-covered grids and left to air dry before being analysed using a Philips CM10 TEM.

Samples from each monitoring site containing high numbers of Pseudo-nitzschia as determined by light microscopy were analysed using TEM. Samples were spread over the growing period from April to September. Helgoland samples from August/September 2005, April 2006, June 2006, July 2006, April 2008, August 2008 and June 2009 and Stonehaven samples from July 1998, July 2002, September 2002, August 2002, July 2003, August 2004, September 2004, April 2007 and June 2007 were analysed. Pseudo-nitzschia cells were identified to species level using criteria described in (Skov et al. 1999; Lundholm et al. 2002, 2003, 2006). As no molecular analysis was performed, $P$. delicatissima is identified as $P$. cf. delicatissima as it is not possible to separate this species from $P$. arenysensis using morphological criteria alone (QuijanoScheggia et al. 2009). Owing to the difficulty in getting sufficient resolution of the poroids, P. pseudodelicatissimalike cells are referred to as $P$. cf. pseudodelicatissima in this study.

\section{Results}

Temperature and salinity

Figures $2 \mathrm{a}-\mathrm{d}$ show the seasonal patterns of temperature and salinity at both sites. The seasonal cycle of temperature is typical of that in the temperate northern hemisphere with the warmest temperatures measured in August/September and the coldest temperatures in February/March. At Stonehaven, in the northern North Sea, the seasonal cycle is less extreme and the lowest temperature observed in the measurement period $(2002-2011)$ was $5.1{ }^{\circ} \mathrm{C}$, while at Helgoland, the lowest temperature measured (2002-2011) was $1.1{ }^{\circ} \mathrm{C}$. The maximum temperatures were considerably higher at Helgoland (varying between 17.0 and $18.7^{\circ} \mathrm{C}$ ) than at Stonehaven (between 12.2 and $16.2{ }^{\circ} \mathrm{C}$ ).

\section{Light microscopy cell counts}

A different seasonality in the occurrence of Pseudo-nitzschia spp. is evident at both sites (Fig. 3a, b). Two different periods of elevated Pseudo-nitzschia cell densities can be observed at the Stonehaven site with an initial increase in 


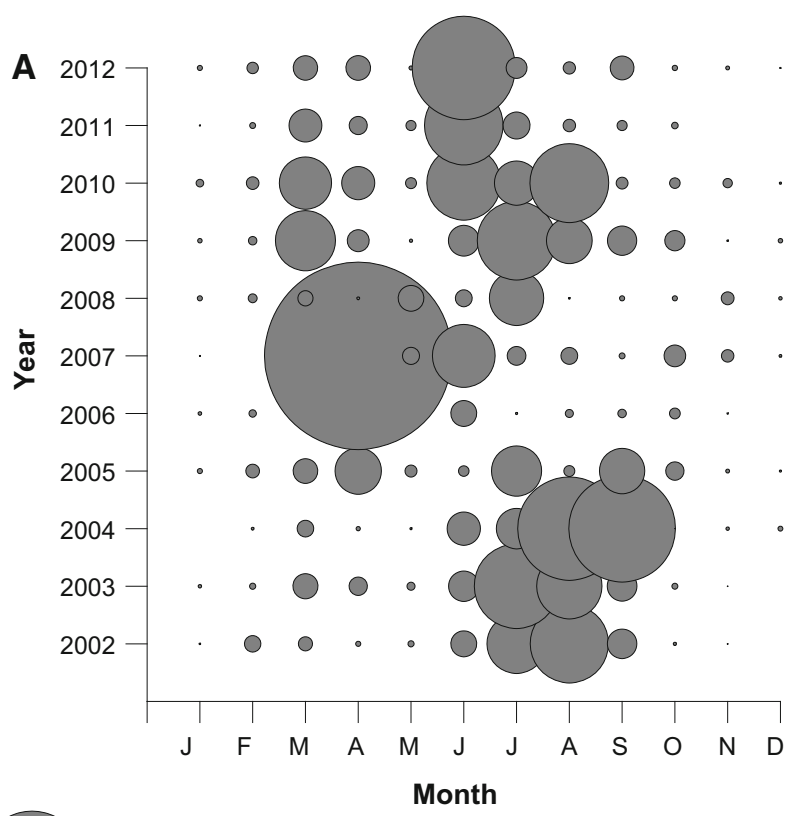

$5.00 \times 105$ cells. $1-1$

$1.25 \times 105$ cells.l-1

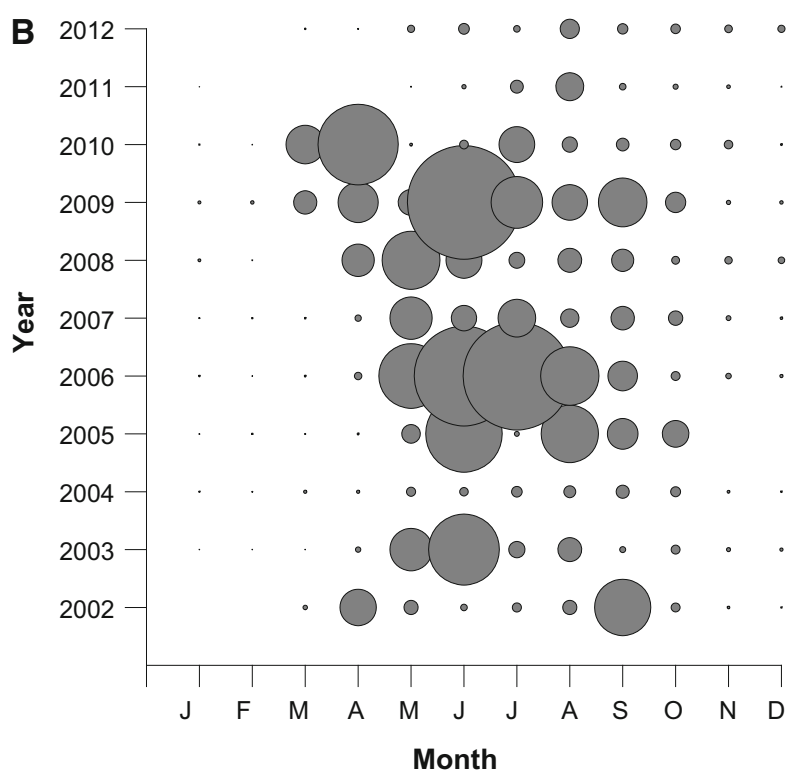

$5.00 \times 105$ cells.l-1

$1.25 \times 105$ cells. ${ }^{-1}$

Fig. 3 Graphs showing monthly averages of Pseudo-nitzschia cell counts from a Stonehaven and b Helgoland Roads sites

numbers in spring during March and April and then a larger bloom in summer or early autumn (Fig. 3a). The intensity of these blooms varied from year to year over the time series with the timing of the highest abundance varying between spring, summer and autumn throughout the time series. The highest cell count of Pseudo-nitzschia species at Stonehaven $\left(1.75 \times 10^{6}\right.$ cells $\left.\mathrm{L}^{-1}\right)$ was recorded during the intense bloom observed during the spring of 2007. Pseudonitzschia cell densities at Helgoland Roads did not observe the same seasonality, and higher cell densities were observed during late spring and early summer (May-July). The highest cell densities were observed during June 2009 when cell densities reached a maximum of $9.25 \times 10^{5}$ cells $\mathrm{L}^{-1}$ (Fig. 3b). In common with the Stonehaven site, the cell densities at Helgoland Roads showed considerable internal variation from year to year with particularly low cell densities observed since 2010. The growing season for Pseudonitzschia species in general was shorter at Helgoland with Pseudo-nitzschia rarely appearing before April and virtually absent also after November in contrast to the Stonehaven site where Pseudo-nitzschia begin to increase from February onwards. Even during the winter months is it usual to record low numbers $\left(100\right.$ cells $\left.\mathrm{L}^{-1}\right)$ in the water column at the Stonehaven monitoring site.

Pseudo-nitzschia as a proportion of the total diatom community

Figure 4a, b show the \% Pseudo-nitzschia cells in the total diatom community at both sites. At Stonehaven, although Pseudo-nitzschia is relatively abundant between February and May, it represents a relatively small \% of the total diatom community $(<10 \%)$. This is due to the very high abundance of other diatom genera such as Skeletonema, Thalassiosira and Chaetoceros, which are dominant components of the spring bloom. During the late summer/early autumn months, the percentage of Pseudo-nitzschia cells in the diatom population increases, comprising between 20-25\% from July to September. In winter months, diatom cell density at Stonehaven is very low $\left(<5,000\right.$ cells L $\left.^{-1}\right)$ and Pseudo-nitzschia cells are often the dominant part of this community (albeit at very low cell densities).

In contrast, Pseudo-nitzschia comprises a much smaller proportion of the diatom population at Helgoland (mostly $<5 \%$ ), with the exception of June when Pseudonitzschia cell densities represent $15 \%$ of the diatom population. The diatom community on Helgoland is very variable on annual scale with Thalassionema nitzschioides, Asterionellopsis and Thalassiosira species as well as Chaetoceros debilis being dominant bloom forming species. Higher diatom cell densities are recorded at Helgoland than at Stonehaven during the autumn and winter, and Pseudo-nitzschia cells comprise a much smaller part of the diatom population during this period.

\section{Pseudo-nitzschia diversity}

Six species of Pseudo-nitzschia were found in samples from Stonehaven (Fig. 5: P. cf. delicatissima, P. pseudodelicatissima, $P$. pungens, $P$. seriata, $P$. australis and 

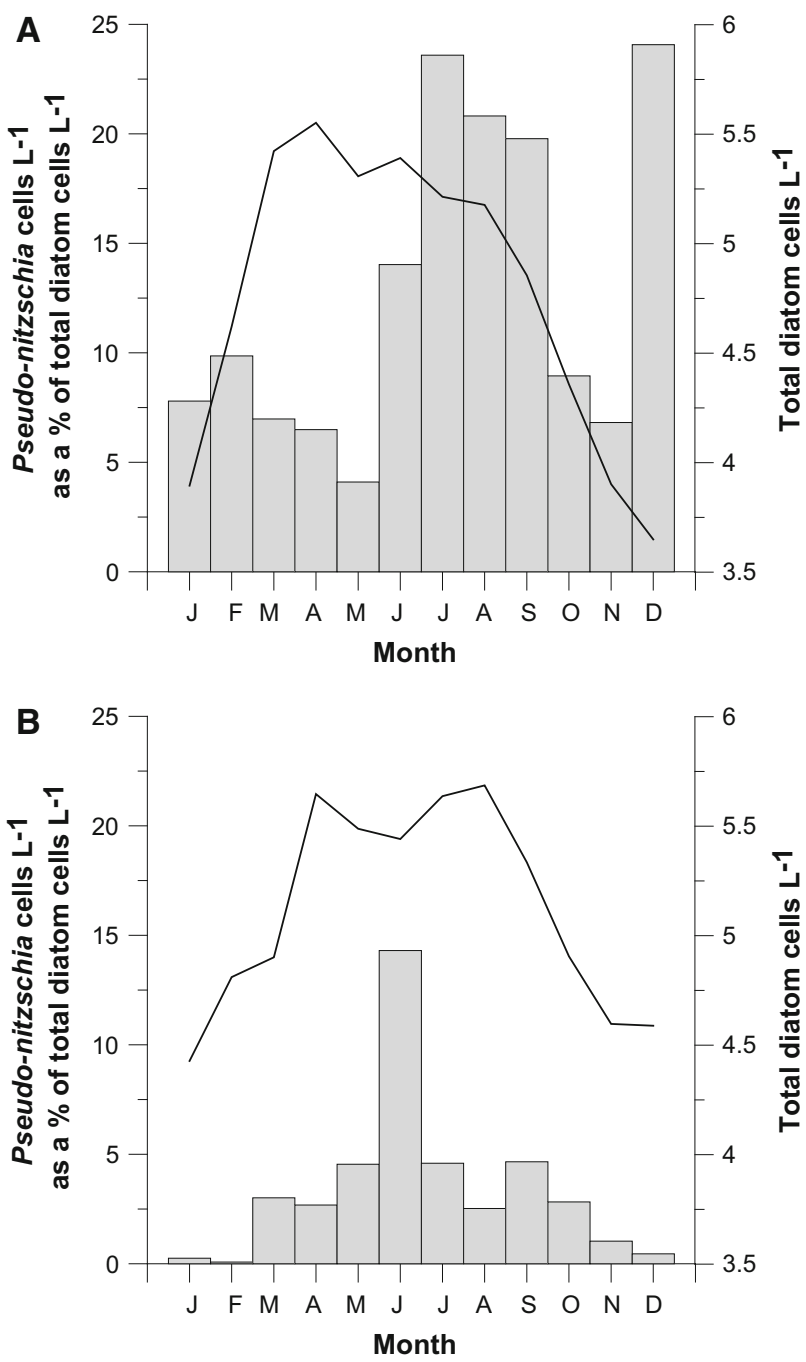

Fig. 4 Plots showing Pseudo-nitzschia cells $\mathrm{L}^{-1}$ as a $\%$ of the monthly averaged total diatom cell count at a Stonehaven and b Helgoland over the duration of the study. Pseudo-nitzschia cells are represented by a bar and the total diatom cell count by the solid line

$P$. subpacifica) and five species were found from Helgoland (Figs. 6, 7: P. americana, $\mathrm{P}$ cf. delicatissima, $P$. fraudulenta, $P$. pungens and $P$. multiseries). The morphological dimensions recorded in the identification of these cells are presented in Table 1. The diversity of the Pseudonitzschia populations at the two sites during different times of year is summarised in Table 2. P. delicatissima and $P$. pseudo-delicatissima were more abundant at the Stonehaven site during the spring time, while $P$. australis, $P$. seriata and $P$. subpacifica were observed only at the Stonehaven site during late summer/early autumn. Only one cell of $P$. subpacifica was observed, collected during August 2004. In contrast to the Stonehaven site, P. multiseries was only observed at the Helgoland site and was detected during both spring and late summer/early autumn.
Although not observed in samples analysed from the Stonehaven site during the course of this study, $P$. multiseries and $P$. americana have previously been recorded at Scottish sites from the west coast (Fehling et al. 2006; Brown and Bresnan 2008). This study is the first record of these species at Helgoland Roads.

\section{Discussion}

Analysis of time -series data is becoming increasingly important to understand long-term changes in marine ecosystems (Wiltshire et al. 2010). A thorough knowledge of regional biodiversity is particularly important with respect to identifying the impacts from environmental and anthropogenic impacts as detailed biodiversity inventories form the baseline for judging future changes (Edwards et al. 2010). Such knowledge is particularly important as recent scenarios of climate change (IPCC 2007) predict considerable temperature increases in marine waters, which are likely to be associated with changes in marine biodiversity including that of harmful species (Peperzak 2003, Moore et al. 2008).

Several Pseudo-nitzschia species are now considered to be cosmopolitan or at least to have a very wide distribution (Hasle 2002; Casteleyn et al. 2008, 2009). Nevertheless, at a regional-scale analysis of time-series data from both the Helgoland and Stonehaven, time series showed considerable differences in the species composition in the examined seasonal samples, with only two species, $P$. delicatissima and $P$. pungens occurring at both sites. New records of two Pseudo-nitzschia species, $P$. multiseries and $P$. americana, were established at Helgoland Roads.

While Pseudo-nitzschia multiseries might be considered a cosmopolitan species (Evans 2004, Doucette et al. 2008) and has also been observed in the southern North Sea, i.e. the Dutch Wadden Sea (Vrieling et al. 1996), the distribution of $P$. americana is much less known, possibly because it is very inconspicuous and under the light microscope does not show the typical Pseudo-nitzschia morphology. It has only been reported infrequently from different locations globally, e.g. the English Channel (Klein et al. 2010), Scotland (Bresnan et al. 2002; Fehling et al. 2006), Bay of Fundy (Kaczmarska et al. 2005), from the Japan and Okhotsk Seas (Orlova and Shevchenko 2002) and also from Australian waters (Hallegraeff 1994) and Denmark (Lundholm et al. 2010). It is sometimes observed on the setae of Chaetoceros cells (Horner 2002).

Both sites differ in their general hydrography with the Helgoland site being very shallow (maximum $8 \mathrm{~m}$ depending on the tide) and exposed to strong currents. It is therefore almost always well mixed. The Stonehaven site is 

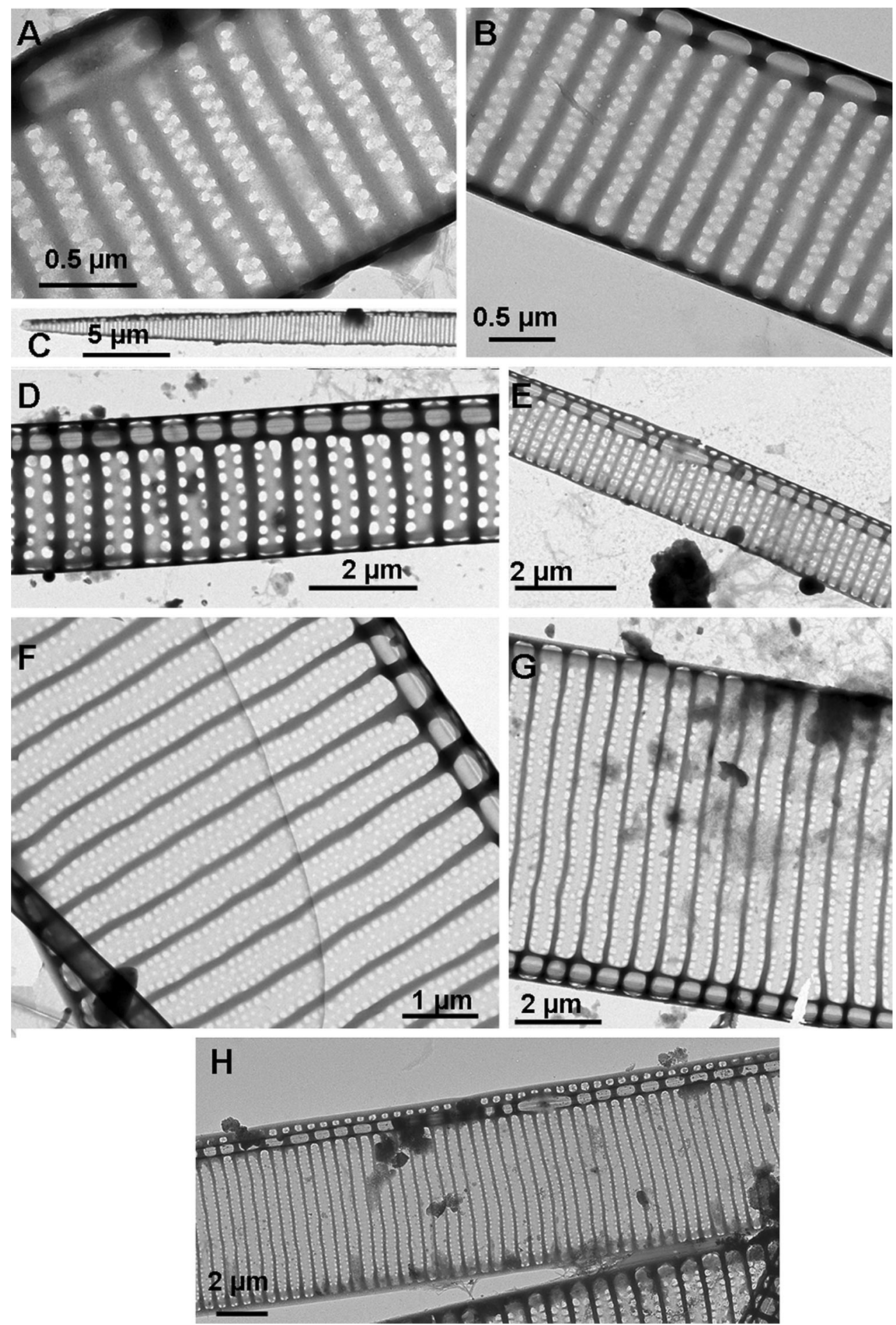

Fig. 5 TEM micrographs of Pseudo-nitzschia species from Stonehaven: a-c $P$. cf. delicatissima, d P. pungens, e P. pseudodelicatissima, $\mathbf{f}$ P. seriata, $\mathbf{g}$ P. australis and $\mathbf{h}$ P. subpacifica

also well mixed but is $50 \mathrm{~m}$ deep with a strong southerly current. At both sites, following the general pattern observed in the North Sea, there is also a long-term trend of increasing temperatures. At the Helgoland Roads site, sea surface temperatures have increased by $1.67^{\circ}$ in the past 45 years (Wiltshire et al. 2010; Holt et al. 2012), a warming rate of $0.37{ }^{\circ} \mathrm{C}$ per decade (Hughes et al. 2009; Wiltshire et al. 2010). Stonehaven follows the warming 

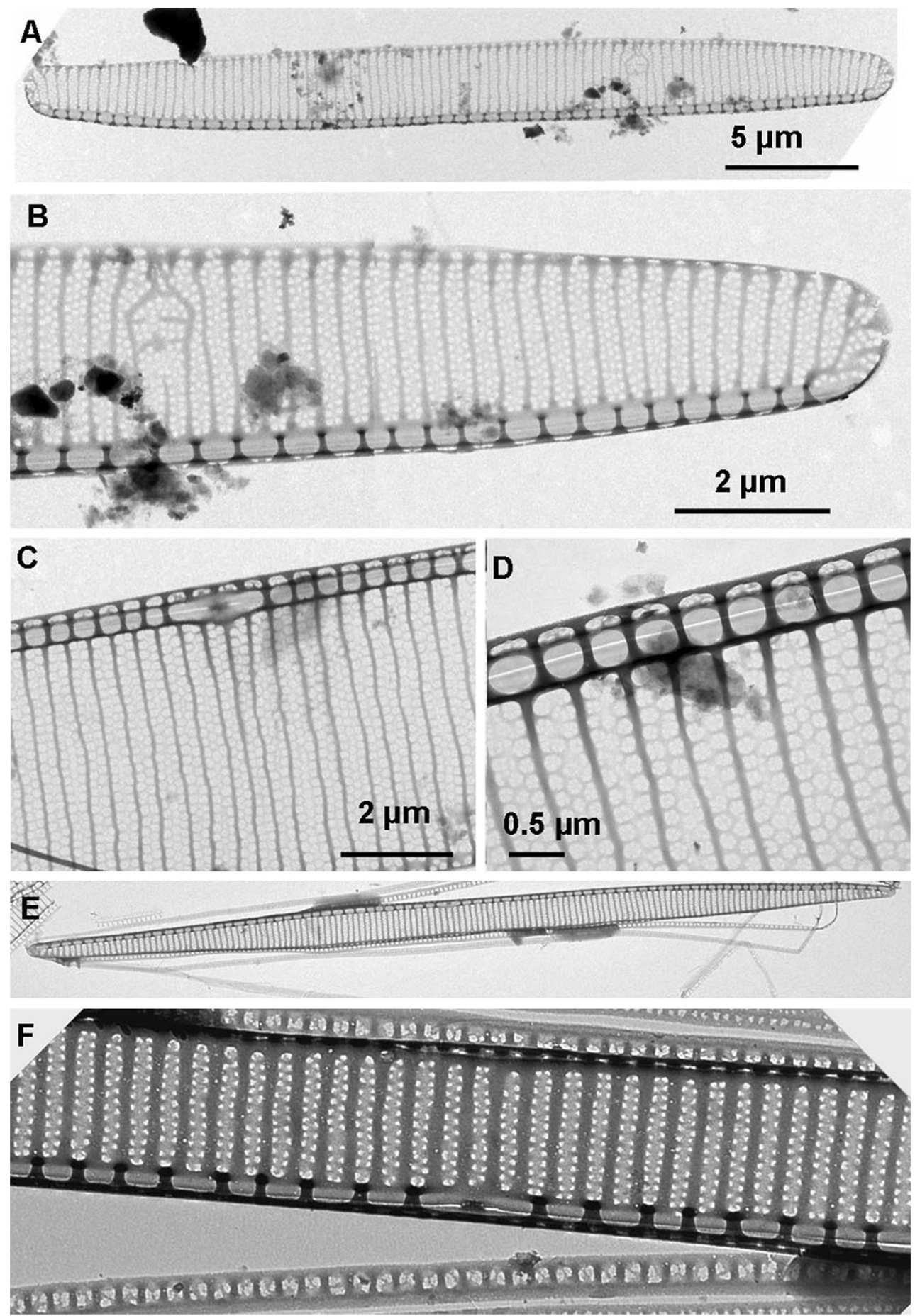

Fig. 6 TEM micrographs of Pseudo-nitzschia species from Helgoland Roads: a-b P. americana, $\mathbf{c}-\mathbf{d}$ P. fraudulenta and e-f P. cf delicatissima

trend observed in the northern North Sea (Hughes et al. 2009), which is slightly lower than that observed further south. In the northern North Sea, warming has occurred at a rate of $0.23^{\circ}$ per decade over the period 1970-2010 (Hughes et al. 2010).
Both sites experience different salinity regimes. At Stonehaven, surface salinity is influenced by a small outflow of freshwater from a nearby river and varies between 32.91 and 34.95. These fresher water episodes only happen once or twice per year, are very short in duration lasting 

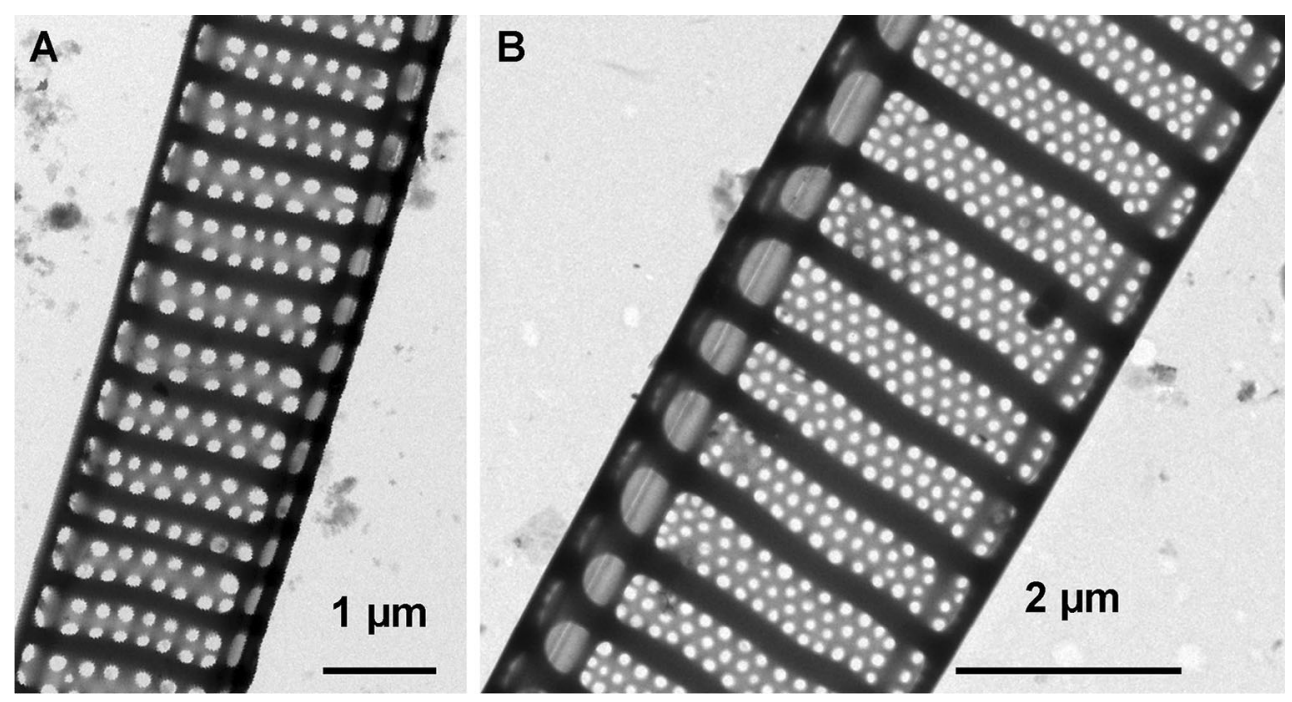

Fig. 7 TEM micrographs of a $P$. pungens and $\mathbf{b}$ P. multiseries from Helgoland Roads time series

Table 1 Morphometric dimensions of Pseudo-nitzschia cells identified using TEM

\begin{tabular}{|c|c|c|c|c|c|c|c|c|}
\hline Species\Metric & Shape & Length & Width & $\begin{array}{l}\text { Central } \\
\text { Interspace }(\mathrm{Y} / \mathrm{N})\end{array}$ & $\begin{array}{l}\text { No. of fibulae } \\
(10 \mu \mathrm{m})\end{array}$ & $\begin{array}{l}\text { No. of striae } \\
(10 \mu \mathrm{m})\end{array}$ & $\begin{array}{l}\text { No. of rows } \\
\text { of poroids }\end{array}$ & $\begin{array}{l}\text { No. of poroids } \\
(1 \mu \mathrm{m})\end{array}$ \\
\hline$P$. americana & rect & $31.6-32.6$ & $2.8-3.2$ & $\mathrm{~N}$ & $19-21$ & 28 & 2 & 9 \\
\hline P. australis & lanc & $80.2-121$ & $7.2-8.2$ & $\mathrm{~N}$ & $14-17$ & $15-18$ & 2 & 5 \\
\hline P. cf. delicatissima & lanc & $45.4-57.3$ & 2.0 & $\mathrm{Y}$ & $22-24$ & 36 & 2 & $8-9$ \\
\hline P. fraudulenta & lanc & $73.3-81.8$ & $5.4-7.0$ & $\mathrm{Y}$ & $21-24$ & $20-24$ & $2-3$ & 6 \\
\hline P. multiseries & lanc & $99.2-190.4$ & $4.5-4.7$ & $\mathrm{~N}$ & $11-14$ & $10-12$ & $3-4$ & 6 \\
\hline$P$. cf. pseudodelicatissima & $\operatorname{lin}$ & 63.34 & 1.21 & $\mathrm{Y}$ & 23 & 39 & 1 & $5-6$ \\
\hline P. pungens & $\operatorname{lin}$ & $106-148$ & $3.4-4.6$ & $\mathrm{~N}$ & $10-12$ & $10-12$ & 2 & 3 \\
\hline P. seriata & lanc & $80.6-120$ & $7.5-8$ & $\mathrm{~N}$ & $14-15$ & $16-17$ & $2(+1 / 2)$ & 8 \\
\hline P. subpacifica & Lanc & 79 & 5.3 & $\mathrm{Y}$ & 16 & 27 & 2 & 9 \\
\hline
\end{tabular}

Linear, lanceolate and rectangular shape of valves is notated as lin, lanc and rect, respectively

Table 2 Seasonal diversity of Pseudo-nitzschia species from TEM results

The observation of the species from in samples from a season is represented by $\mathrm{H}$ (samples from Helgoland), S (samples from Stonehaven) or - (not observed in samples)

\begin{tabular}{llll}
\hline Species & Spring (March/April) & Summer (May/June/July) & Autumn (August/September) \\
\hline P. americana & $\mathrm{H},-$ & $\mathrm{H},-$ &,-- \\
$P$. australis &,-- &,$- \mathrm{S}$ &,$- \mathrm{S}$ \\
$P$. cf. delicatissima & $\mathrm{H}, \mathrm{S}$ &,-- &,-- \\
$P$. fraudulenta & $\mathrm{H}, \mathrm{S}$ & $\mathrm{H},-$ &,-- \\
$P$. multiseries & $\mathrm{H},-$ & $\mathrm{H},-$ &,-- \\
$P$. pungens & $\mathrm{H},-$ & $\mathrm{H}, \mathrm{S}$ & $\mathrm{H}, \mathrm{S}$ \\
$P$. pseudodelicatissima &,$- \mathrm{S}$ &,-- &,-- \\
$P$. seriata &,-- &,$- \mathrm{S}$ &,$- \mathrm{S}$ \\
$P$. subpacifica &,-- &,-- &,$- \mathrm{S}$ \\
\hline
\end{tabular}

less than a week and are confined to the surface layers. Nearbed salinity is generally 34.1 , with a median value of 34.53. The coastal waters surrounding Helgoland are much fresher as a result of the large quantities of freshwater entering the coastal regions in the German Bight (Holliday et al. 2010). Salinity at Helgoland ranged from 23.71 to 
36.11 (although such extreme values are recorded very infrequently), and interannual variability was high.

It is possible that Atlantic inflow may influence the species composition within the Pseudo-nitzschia genus in the North Sea and may contribute to the higher diversity in areas exposed to Atlantic waters. For instance, Pseudonitzschia australis and seriata as well as closures of shellfish harvesting areas as a result of high concentrations of ASP in shellfish flesh have been observed along the Atlantic coasts of Spain, Portugal, France, Ireland and Scotland (Lelong et al. 2012; Trainer et al. 2012) while the occurrence of confirmed DA-producing species and ASP closures in the southern North Sea has been much less frequently observed. Examination of the ecological importance of Pseudo-nitzschia genus at both sites shows that Pseudo-nitzschia comprises a larger portion of the diatom population at the Stonehaven monitoring site than at the Helgoland. This is particularly apparent from July to December when diatom cell abundance can be dominated by Pseudo-nitzschia, and this may have implications for the transfer of DA through the marine food web. In contrast, at Helgoland, blooms of other genera such as Chaetoceros, Guinardia, Leptocylindrus and since 2010, Mediopyxis helysia can dominate the community.

Historic investigations into the diversity of Pseudonitzschia species in the North Sea are scarce. Hasle et al., (1996) observed a shift from $P$. multiseries to $P$. pungens in the Skaggerak during the 1970s and 1980s and attributed this to increasing water temperatures. P. multiseries has a greater tolerance for low water temperatures, and this may be reflected in the distribution observed in this study (Hasle 1995). Averaged winter temperatures in Scottish coastal waters rarely dip below $5{ }^{\circ} \mathrm{C}$ (Holt et al. 2012), while in Helgoland these temperatures are frequently observed. Despite the observed increase in annually averaged temperatures since 1962 and the disappearance of incidences of sea ice in winter, winter temperatures frequently drop as low as $2-3{ }^{\circ} \mathrm{C}$.

The diversity of Pseudo-nitzschia species in a sediment core from a Danish fjord also revealed a number of diversity changes in European waters over several decades (Lundholm et al. 2010). A shift towards a P. pungens dominated community was correlated with increasing nitrate input and increasing temperatures, while an isolated bloom of $P$. americana was correlated with ammonia input. Both of these studies highlight the transient nature of Pseudo-nitzschia community diversity and how species dominance can be influenced by environmental variables. A recent investigation by Hinder et al. (2012) has related the increase in Pseudo-nitzschia abundance observed in the Continuous Plankton Recorder data since the mid-1990 s with an increase in wind speed and intensity. No investigations have been carried out yet to investigate whether this change in abundance is associated with a change in diversity; however, Hasle et al. (1996) and Lundholm et al. (2010) both observe a decrease in the DA-producing $P$. multiseries in the Northern North Sea over the last number of decades.

This study provides the first genus-level comparison study of the diversity of Pseudo-nitzschia between two longterm time series within the North Sea. Pseudo-nitzschia is a key member of the phytoplankton community at both of these sites, and differences observed in seasonal abundances and community composition within a single diatom genus highlight the difficulties in making ecological status based assessments on a regional sea scale. For the genus Pseudonitzschia, this is particularly pertinent, as this genus contains a large number of species that are difficult to identify with the easy-to-use methodologies available to those carrying out routine monitoring. In most areas, including those in this study where detailed assessments were carried out, species diversity within this genus was much higher than previously known. This shows the importance of having baseline diversity data which can facilitate the identification of community changes which may occur over a number of decades. For toxin-producing genera such as Pseudo-nitzschia, this is particularly important as the recent observation of DA in seals in the North Sea (Hall and Frame 2010) highlights the requirement to understand the dynamics of this toxin-producing genus from an ecological view as well as to advise the aquaculture industry.

Acknowledgments The authors wish to thank Mr Kevin McKenzie and Mr Alastair McKinnon from the Microscopy Unit, Institute of Medical Sciences, University of Aberdeen for their assistance with the TEM analysis. AK wishes to thank the Marbef Network of Excellence for providing travel funds to perform the TEM analyses in Aberdeen. Long-term monitoring at the Stonehaven site is funded under the Scottish Government Schedule of Service ST03p. Longterm monitoring at Helgoland is funded by federal and local agencies. The authors acknowledge all staff, past and present, at Marine Scotland Science, UK and the Alfred Wegner Institute, Germany who have assisted with collection and analysis of samples. EB would like to thank Prof Nina Lundholm, University of Copenhagen for her assistance with the identification of $P$. subpacifica. EB and AK also acknowledge the organisers of the 9th Advanced Phytoplankton Course (APC9) who created the stimulating environment where the concept for this manuscript was initiated.

\section{References}

Bresnan, E (2002) Monitoring Programme for Toxic Phytoplankton in Scottish Coastal Waters. April 2001-30 March 2002. FRS Internal Report No.01/02

Bresnan E, Davidson K, Gowen RJ, Higman W, Lawton L, Lewis J, Percy L, McKinney A, Milligan SP, Shammon T, Swann S (2008) Harmful phytoplankton in UK waters: current and future organisms of concern. In: Relating harmful phytoplankton to shellfish poisoning and human health, pp 11-15 
Bresnan E, Hay S, Hughes SL, Fraser S, Rasmussen J, Webster L, Slesser G, Dunn J, Heath MR (2009) Seasonal and interannual variation in the phytoplankton community in the north east of Scotland. J Sea Res 61:17-25

Brown L, Bresnan E (2008) Seasonal occurrence of Pseudo-nitzschia species in the west coast and Shetland Isles, Scotland. In: Proceedings of the 12th international conference on harmful algae. Intergovernmental Oceanographic Commission of UNESCO, Copenhagen, p 165-167

Casteleyn G, Chepurnov VA, Leliaert F, Mann DG, Bates SS, Lundholm N, Rhodes L, Sabbe K, Vyverman W (2008) Pseudonitzschia pungens (Bacillariophyceae): A cosmopolitan diatom species? Harmful Algae 7:241-257

Casteleyn G, Evans KM, Backeljau T, Dhondt S, Chepurnov VA, Sabbe K, Vyverman W (2009) Lack of population genetic structuring in the marine planktonic diatom Pseudo-nitzschia pungens (Bacillariophyceae) in a heterogeneous area in the Southern Bight of the North Sea. Mar Biol 156:1149-1158

Costa PR, Garrido S (2004) Domoic acid accumulation in the sardine Sardina pilchardus and its relationship to Pseudo-nitzschia diatom ingestion. Mar Ecol Prog Ser 284:261-268

Doucette GJ, King KL, Thessen AE, Dortch Q (2008) The effect of salinity on domoic acid production by the diatom Pseudonitschia multiseries. Nova Hedwigia (Beih) 133:31-46

Downes-Tettmar N, Rowland S, Widdicombe C, Woddward M, Llewellyn C (2013) Seasonal variation in Pseudo-nitzschia spp. and domoic acid in the Western English Channel. Cont Shelf Res 53:40-49

Drebes G, Elbrächter M (1976) A checklist of planktonic diatoms and dinoflagellates from Helgoland and List (Sylt), German Bight. Bot Mar 19:75-83

Edwards M, Beaugrand G, Hays GC, Koslow JA, Richardson AJ (2010) Multidecadal oceanic ecological datasets and their application in marine policy and management. Trends Ecol Evol $25: 602-610$

Evans KM (2004) Microsatellite marker development and genetic variation in the toxic marine diatom Pseudo-nitzschia multiseries (Bacillariophyceae). J Phycol 40:911-920

Fehling J, Green DH, Davidson K, Bolch CJ, Bates SS (2004) Domoic acid production by Pseudo-nitzschia seriata (Bacillariophyceae) in Scottish waters. J Phycol 40:622-630

Fehling J, Davidson K, Bolch CJ, Tett P (2006) Seasonality of Pseudo-nitzschia spp. (Bacillariophyceae) in western Scottish waters. Mar Ecol Prog Ser 323:91-105

Franke H-D, Buchholz F, Wiltshire KH (2004) Ecological long-term research at Helgoland (German Bight, North Sea): retrospect and prospect-an introduction. Helgol Mar Res 58:223-229

Gallacher S, Howard G, Hess P, MacDonald E, Kelly MC, Bates LA, Brown N, MacKenzie M, Gillibrand P, Turrell WL (2001) The occurrence of amnesic shellfish poisons in shellfish from Scottish waters. UNESCO, Paris, pp 30-33

Hall AJ, Frame E (2010) Evidence of domoic acid exposure in harbour seals from Scotland: A potential factor in the decline in abundance? Harmful Algae 9:489-493

Hallegraeff GM (1994) Species of the diatom genus Pseudo-nitzschia in Australian waters. Bot Mar 37:397-411

Hasle GR (1995) Pseudo-nitzschia pungens and Pseudo-nitzschia multiseries (Bacillariphyceae); nomenclatural history, morphology and distribution. J Phycol 31:428-435

Hasle GR (2002) Are most of the domoic acid-producing species of the diatom genus Pseudo-nitzschia cosmopolites? Harmful Algae 1:137-146

Hasle GR, Lange CB, Syvertsen EE (1996) A review of Pseudonitzschia, with special reference to the Skagerrak, North Atlantic and adjacent waters. Helgolander Meeresunters 50:131-175
Hinder SL, Hays GC, Edwards M, Roberts EC, Walne AW, Gravenor MB (2012) Changes in marine dinoflagellate and diatom abundance under climate change. Nat Climate Change 2:271-275

Holliday, NP, Hughes, SL, Dye, S, Inall, M, Read, J, Shammon, T, Sherwin, T, Smyth, T (2010) Salinity. MCCIP Annual Report Card 2010-11, MCCIP Science Review, p 10

Holt JS, Hughes S, Hopkins J, Wakelin SL, Holliday NP, Dye SR, Gonzalez-Pola C, Hjollo SS, Mork KA, Nolan G, Proctor R, Read J, Shammon T, Sherwin T, Smyth T, Tatersall G, Ward B, Wiltshire KH (2012) Multi-decadal variability and trends in the temperature of the northwest European continental shelf: a model-data synthesis. Prog Oceanogr 106:96-117

Hoppenrath M (2004) A revised checklist of planktonic diatoms and dinoflagellates from Helgoland (North Sea, German Bight). Helgol Mar Res 58:243-251

Horner RA (2002) A taxonomic guide to some common marine phytoplankton. Biopress Ltd, Bristol

Hughes SL, Holliday NP, Colbourne E, Ozhigin V, Valdimarsson H, Østerhus S, Wiltshire K (2009) Comparison of in situ time-series of temperature with gridded sea surface temperature datasets in the North Atlantic. ICES J Mar Sci 66:1467

Hughes, SL, Holliday, NP, Kennedy, J, Berry, DI, Kent, EC, Sherwin, T, Dye, S, Inall, M, Shammon, T, Smyth, T (2010) Temperature (air and sea). MCCIP Annual Report Card 2010-11, MCCIP Science Review, p 16

IPCC (2007) Climate change 2007: Synthesis report. Contribution of working groups I, II and III to the fourth assessment report of the intergovernmental panel on climate change., [Core writing team P, R. K., Reisinger, A.] (eds), Geneva, Switzerland

Kaczmarska I, LeGresley MM, Martin JL, Ehrmann J (2005) Diversity of the diatom genus Pseudo-nitzschia Peragallo in the Quoddy Region of the Bay of Fundy, Canada. Harmful Algae 4:1-19

Klein C, Claquin P, Bouchart V, Le Roy B, Veron B (2010) Dynamics of Pseudo-nitzschia spp. and domoic acid production in a macrotidal ecosystem of the eastern english channel (Normandy, France). Harmful Algae 9:218-226

Krock B, Tillmann U, Alpermann TJ, Voss D, Zielinski O, Cembella AD (2013) Phycotoxin composition and distribution in plankton fractions from the German Bight and western Danish coast. J Plankton Res 35:1093-1108

Lelong A, Hegaret H, Soudant P (2012) Pseudo-nitzschia (Bacillariophyceae) species, domoic acid and amnesic shellfish poisoning: revisiting previous paradigms. Phycologia 51:168-216

Löder MGJ, Kraberg A, Aberle N, Peters S, Wiltshire KH (2012) Dinoflagellate and ciliates at Helgoland Roads, North Sea. Helgol Mar Res 66:11-23

Lund JWG, Kipling C, Le Cren ED (1958) The inverted microscope method of estimating algal numbers and the statistical basis of estimations by counting. Hydrobiologia 11:143-170

Lundholm N, Hasle GR, Fryxell GA, Hargraves P (2002) Morphology, phylogeny and taxonomy of species within the Pseudonitzschia americana complex (Bacillariophyceae) with descriptions of two new species, Pseudo-nitzschia brasiliana and Pseudo-nitzschia linea. Phycologia 41:480-497

Lundholm N, Moestrup Ø, Hasle GR, Hoef-Emden K (2003) A study of the Pseudo-nitzschia pseudodelicatissima/ cuspidata complex (Bacillariophyceae): What is $P$. delicatissima? $\mathrm{J}$ Phycol 39:797-813

Lundholm N, Moestrup Ø, Kotaki Y, Hoef-Emden K, Scholin C, Miller P (2006) Inter- and intraspecific variation of the Pseudonitzschia delicatissima complex (Bacillariophyceae) illustrated by rRNA probes, morphological data and phylogenetic analyses. J Phycol 42:464-481 
Lundholm N, Clarke A, Ellegaard M (2010) A 100-year record of changing Pseudo-nitzschia species in a sill-fjord in Denmark related to nitrogen loading and temperature. Harmful Algae 9:449-457

McQuatters-Gollop A (2012) Challenges for implementing the Marine Strategy Framework Directive in a climate of macroecological change. Philos Trans R Soc Math Phys Eng Sci 370:5636-5655

Moore SK, Trainer VL, Mantua NJ, Parker MS, Laws EA, Backer LC, Fleming LE (2008) Impacts of climate variability and future climate change on harmful algal blooms and human health. Environ Health. doi:10.1186/1476-1069X-1187-S1182-S1184

Orlova TY, Shevchenko OG (2002) The first record of Pseudonitzschia americana (Bacillariopyta) for the seas of Russia. Biol Morya 28:372-375

Peperzak L (2003) Climate change and harmful algal blooms in the North Sea. Acta Oecol 24:S139-S144

Percy L, Higman W, Bateman K, Bresnan E, Morris S, Lewis J (2006) An investigation of the relationship between Pseudo-nitzschia species and domoic acid in Mytilus sp. in the Fal estuary. In: 12th international conference on harmful algae, Copenhagen, Denmark, 4-8 Sept

Quijano-Scheggia SI, Garces E, Lundholm N, Moestrup Ø, Andree K, Campi J (2009) Morphology, physiology molecular phylogeny and sexual compatibility of the cryptic Pseudo.nitzschia delicatissima complex (Bacillariophyta) including the description of Parenysensis sp nov. Phycologia 48:492-509

Skov J, Lundholm N, Moestrup Ø, Larsen J (1999) Potentially toxic phytoplankton: 4. The diatom genus Pseudo-nitzschia (Diatomophyceae/Bacillariophyceae). ICES Identification leaflets for
plankton=Fisches d'identification du plancton, 185, (eds), Copenhagen

Throndsen J (1978) Preservation and storage. In: Sournia A (ed) Phytoplankton 483 manual. UNESCO, Paris, pp 69-74

Trainer V, Bates SS, Lundholm N (2012) Pseudo-nitzschia physiological ecology, phylogeny, toxicity, monitoring and impacts on ecosystem health. Harmful Algae 14:271-300

Turrell E, Bresnan E, Collins C, Brown L, Graham J, Grieve M (2008) Detection of Pseudo-nitzschia (Bacillariophyceae) species and amnesic shellfish toxins in Scottish coastal waters using oligonucleotide probes and the Jellet Rapid Test (TM). Harmful Algae 7:443-458

Villac MC, Rielke DL, Villareal TA, Fryxell GA (1993) Comparison of two domoic acid-producing diatoms: a review. Hydrobiologia 269(270):213-224

Vrieling EG, Koeman RPT, Peperzak L, Veenhuis M, Scheerman P, Gieskes WWC (1996) Pseudo-nitzschia pungens forma multiseries and other Pseudo-nitzschia species in the Dutch Wadden Sea. Harmful and toxic algal blooms. UNESCO, Paris, pp 139-142

Wiltshire KH, Malzahn AM, Wirtz K, Greve W, Janisch S, Mangelsdorf P, Manly BFJ, Boersma M (2008) Resilience of North Sea phytoplankton spring bloom dynamics: an analysis of long-term data at Helgoland Roads. Limnol Oceanogr 53:1294-1302

Wiltshire KH, Kraberg A, Bartsch I, Boersma M, Franke HD, Freund J, Gebühr C, Gerdts G, Stockmann K, Wichels A (2010) Helgoland roads: 45 years of change in the North Sea. Estuaries Coasts 33:295-310 